Jurnal Interpretasi Hukum |ISSN: 2746-5047

Vol. 2, No. 2 - April 2021, Hal.384-390 | Tersedia online di

https://www.ejournal.warmadewa.ac.id/index.php/juinhum

DOI : https://doi.org/10.22225/juinhum.2.2.3445.384-390

\title{
PENEGAKAN HUKUM TERHADAP TINDAK PIDANA PENYELUNDUPAN PENYU SEBAGAI SATWA TERLINDUNGI DI BALI
}

\author{
I Komang Arya Sentana Mahendra, Anak Agung Sagung Laksmi Dewi \& Luh Putu Suryani \\ Fakultas Hukum Universitas Warmadewa, Denpasar-Bali, Indonesia \\ komangaryasentana@gmail.com, laksmiidewii@gmail.com, putusuryani099@gmail.com
}

\begin{abstract}
Abstrak
Larangan semua eksploitasi hewan yang dilindungi. Bahkan di wilayah Indonesia, penyelundupan penyu masih terjadi, terutama di Provinsi Bali yang sering terjadi penyelundupan penyu. Penelitian ini bertujuan untuk menelaah bentuk perlindungan hukum terhadap penyu sebagai satwa yang dilindungi dan sanksi pidana terhadap pelaku penyeludupan penyu sebagai satwa yang dilindungi. Metode penelitian yang digunakan hukum normatif, dengan menggunakan pendekatan perundang-undangan dan pendektan konseptual. Hasil penelitian menunjukkan bahwa bentuk perlindungan hukum terhadap penyu, jika dari Internasional dengan dibuatnya perjanjian CITES (Convention on International Trade in Endangered Species), di Indonesia terdapat 6 dari 7 jenis penyu yang ada di dunia yang dilindungi berdasarkan undang-undang jenis penyu yang ada di dunia yang dilindungi berdasarkan undang-undang tentang penetapan jenis-jenis binatang liar yang dilindungi, dan bentuk sanksi terhadap orang yang menyelundupkan penyu sebagai satwa yang dilindungi adalah berupa sanksi admisnistratif, sanksi perdata dan sanksi pidana. Sanksi pidana secara mengkhusus terhadap pelaku penyeludupan penyu belum ada, sanksi tersebut masih tergabung dalam Undang-undang No. 5 Tahun 1990 disimpulkan bahwa perlindungan hukum serta sanksi terhadap penyu sebagai satwa yang dilindungi berupa sansi Administratif, perdata, dan pidana, secara mengkhusus di bali sanksi pidana terhadap pelaku penyeludupan penyu belum ada.
\end{abstract}

Kata Kunci: Perlindungan hukum, Penegakkan hukum, Penyelundupan Penyu.

\begin{abstract}
Prohibition of all exploitation of protected animals. Even in the territory of Indonesia, turtle smuggling still occurs, especially in Bali Province where turtle smuggling often occurs. The purpouses of this research are to analyze the legal protection of turtles as protected animals and the criminal sanctions against the perpetrators of turtle smuggling as protected animals? The research method used is normative law, with statutory apporoach and conceptual approach. The results of the research show that forms of legal protection against turtles, if from the international agreement with the CITES agreement (Convention on International Trade in Endangered Species), in Indonesia there are 6 out of 7 types of turtles in the world that are protected under the turtle species law. existing in the protected world based on the law on the determination of wild protected animals, and the forms of sanctions against people who smuggle turtles as protected animals are in the form of administrative sanctions, civil sanctions and criminal sanctions. There are no specific criminal sanctions against turtle smugglers, these sanctions are still incorporated in Law No. 5 of 1990, concluded that legal protection and sanctions against turtles as protected animals in the form of administrative, civil and criminal sanctions, specifically in Bali there are no criminal sanctions against turtle smugglers.
\end{abstract}

Keyword: Law enforcement, Smuggling, Legal protection

\section{PENDAHULUAN}

Indonesia merupakan sebuah negara yang kaya akan sumber daya alam, sumber daya alam dan sumber daya non hayati. Ekosistem memegang peran yang sangat besar. Sehingga perlu dijaga oleh Negara itu sendiri, SDA dan ekosistem Indonesia memiliki kedudukan dan peran penting dalam kehidupan merupakan anugerah, sehingga dalam menjaga dibuatkan sebuah payung hukum yang akan menguatkan keberadaan SDA, serasi, dan seimbang untuk membawa manfaat bagi lndonesia, khususnya seluruh umat manusia. Menurut UUD Negara Republik lndonesia Pasal 33 ayat (3) 1945, tanah, air, serta sumber daya alam yang terkandung di dalamnya dikuasai oleh negara dan digunakan untuk sebesar-besar kemakmuran rakyat.

Sumber daya alam hayati adalah setiap sumber daya alam yang berasal dari makhluk hidup, dalam bahasa asing sumber daya alam hayati disebut biological resources. Menurut data yang 
dimutakhirkan, sumber daya alam yang dapat dimutakhirkan juga mencakup sumber daya alam hayati, seperti sumber daya hewan atau hewan, sumber daya tumbuhan, dan mikroorganisme (Darajati, 2020). Dengan kayanya sumber daya Indonesia, hal ini memancing oknum-oknum tak bertanggung jawab untuk mengambil keuntungan dari sumber daya hayati. Banyak kasus yang sudah terjadi di Indonesia tapi tidak memberikan efek jera kepada para pelaku.

Diantara semua kasus yang terjadi, banyak terjadi kesenjangan hukum sehingga terjadi banyak celah untuk membobol aturan hukum tersebut. Dan ini menjadi catatan penting bagi pemerintah untuk mencari solusinya. Salah satu kasus yang paling sering terjadi pelanggaran adalah penyelundupan hewan langka, yang mana merupakan kasus umum dimana banyak celah untuk melakukannya, karena kelonggaran aturan dan pengawasannya.

Ada banyak ragam hewan langka salah satu diantaranya Penyu termasuk purba dan langka yang dilindungi oleh pemerintah. Akibat gangguan dari manusia, predator, lingkungan dan penyu itu sendiri, kehidupan penyu kini semakin terancam punah. Negara-negara di seluruh dunia telah menandatangani perjanjian yang disebut "Convention on International Trade in Endangered Species" (CITES), yang merupakan perjanjian internasional antar pemerintah (negara anggota), ditandatangani di Washington, DC pada tanggal 3 Maret 1973 (Lovei, 2005). Ini kemudian direvisi di Bonn, Jerman Barat pada bulan Juni. Keputusan No. 22 Tahun 1979 kemudian disetujui dengan Keputusan Pemerintah No. 23. Konvensi No. 43 Tahun 1978. Tujuan dari Convention on International Trade in Endangered Species salah satunya untuk melindungi pasar internasional spesies hewan dan tumbuhan liar (atau bagian dan produk olahannya, yaitu produk yang dibuat dari bagiannya) tidak mengancam kelestariannya. Konvensi Perdagangan Internasional yang Terancam Punah. Convention on International Trade in Endangered Species merupakan kesepakatan yang memuat tiga lampiran (lampiran), antara lain:

- Lampiran I mencantumkan dan melindungi semua spesies hewan dan tumbuhan yang secara komersial terancam oleh berbagai bentuk perdagangan internasional,

- Lampiran II, mencantumkan spesies yang tidak punah, tetapi jika perdagangan berlanjut tanpa pengawasan, spesiesnya mungkin akan punah,

- Lampiran III dokumen ini mencantumkan daftar perlindungan spesies tumbuhan dan hewan liar tertentu di habitat negara / kawasan tertentu, dan memberikan pilihan kepada negaranegara anggota CITES, jika suatu hari mempertimbangkan untuk memasukkannya ke dalam Apendiks II atau bahkan Apendiks 1.

Penyu (kuran-kura) dalam internasional telah masuk dalam Appendix 1 Convention on International Trade in Endangered Species of Wild Fauna and Flora, artinya penyu telah dinyatakan terancam punah dan tidak dapat diperdagangkan dalam bentuk apapun. Tanggal 5 tahun 1990 tentang perlindungan alam Sumber Daya (selanjutnya disebut "UU KSDAHE") merupakan payung hukum perlindungan berbagai hewan dan tumbuhan (salah satunya kura-kura). UU KSDAHE secara tegas melarang penggunaan satwa dilindungi untuk aktivitas apapun. Pasal 21 (2). Peraturan Negara Republik Indonesia tentang Pemanfaatan Jenis Satwa dan Tumbuhan tanggal 8 Agustus 1999 merupakan hukum bagi perlindungan berbagai jenis satwa dan tumbuhan (salah satunya penyu). Pasal 56 mengatur Peraturan Pemerintah Nomor 8 Tahun 1999 tentang Pemanfaatan Jenis Satwa Liar dan Tumbuhan:

- Satu, setiap orang yang memperdagangkan satwa liar dilindungi undang-undang dilarang karena telah melanggar Pasal 21 Undang-Undang Nomor 5 Tahun 1990 tentang perlindungan sumber daya alam hayati dan ekosistemnya.

- Dua, tindakan sebagaimana dimaksud pada ayat (1) dapat dikenakan denda administrasi paling banyak dua miliar rupiah dan / atau pencabutan izin usaha terkait.

Namun pada kenyataannya, undang-undang tersebut tidak dapat secara efektif menyelesaikan permasalahan terkait penyelundupan penyu. Bahkan di Indonesia, khususnya di Bali, penyelundupan penyu masih terus berlangsung. Meski polisi telah berhasil menggagalkan kegiatan penyelundupan penyu di Bali, namun praktik penyelundupan penyu masih marak. Seperti penyelundupan penyu hijau ke Turki yang gagal dilakukan oleh polisi. Selain itu, penyelundupan penyu ke Bali juga melibatkan 
oknum Polda Bali. Pada 27 April (27 Desember 2019), lembaga swadaya masyarakat Pro Fauna menangkap seorang anggota Polres Bali yang tidak etis di Pantai Pandawa Kuta, berinisial MR. Menurut Badan Perlindungan Hewan (KSBK) beberapa waktu lalu, perdagangan olahan penyu atau kura-kura hijau itu masih dibiarkan. Mulai dari rumah makan besar hingga pedagang kecil, terdapat rumah makan yang menjual daging penyu cangkang lunak di beberapa tempat di daerah Bali hal ini tidak pun ditanggapi oleh polisi. Artinya, perdagangan penyu di Bali masih berlangsung. Dan terjadi begitu saja, tanpa ada rasa jera ataupun takut untuk melanggar. Kita tahu bahwa kegiatan penegakan hukum terhadap satwa liar yang dilindungi telah dilaksanakan dan ada undang-undang terkait yang mengawasi mereka, sedangkan dilihat dari kejadian yang terjadi di lokasi kejadian, masih terdapat kasus penyelundupan penyu yang menunjukkan masih adanya penangkapan. sering Pencurian atau bahkan pembunuhan hewan liar: barang yang dilindungi dapat diperdagangkan. Oleh karena itu, perlu adanya penegakan hukum terhadap penyelundup. Menurut Satjipto Raharjo, penegakan hukum pada hakikatnya adalah pelaksanaan konsep seperti keadilan, kebenaran, dan kesejahteraan masyarakat. Oleh karena itu, penegakan hukum merupakan upaya untuk mewujudkan gagasan dan konsep tersebut (Rajardjo, 2006).

Ada beberapa penelitian terdahulu yang relevan dengan penelitian ini. (Syahni, 2018) membahas mengenai penegakan hukum terhadap tindak pidana penyelundupan penyu sebagai satwa terlindungi dengan menggunakan Undang-undang Nomor 5 Tahun 1990 tentang konservasi sumber daya alam hayati dan Ekosistemnya. Perlindungan hukum bagia satwa juga terdapat pada KEPRES Nomor 43 Tahun 1978 Tentang Konvensi Perdagangan Internasional Terhadap Jenis-Jenis Yang Terbahaya Dari Fauna Dan Flora Liar di Indonesia (Putra, 2019). Dalam penelitian Zanita (2019) membahas Penyelesaian Hukum kasus tindak pidana terhadap pembunuhan satwa yang dilindungi berdasarkan Undang-Undang Nomor 5 Tahun 1990.

\section{METODE PENELITIAN}

Metode penelitian yang digunakan adalah jenis penelitian hukum yang mengkaji hukum perundang-undangan dari segala aspek, tetapi tidak mengkaji penerapan atau aspek pelaksanaannya atau sering disebut normatif. Namun untuk metode permasalahan yang digunakan adalah metode hukum dan metode konseptual. Metode statutori adalah metode yang dilaksanakan dengan memeriksa semua peraturan perundang-undangan yang berkaitan dengan masalah (problem legal yang dihadapi), dan cara ini berbeda dengan peraturan perundang-undangan dan doktrin yang dirumuskan dalam ilmu hukum untuk memberikan definisi hukum untuk memperjelas gagasan. hukum yang terkait dengan masalah tersebut

\section{HASIL DAN PEMBAHASAN}

\section{Perlindungan Hukum Terhadap Penyu Sebagai Satwa Yang Dilindungi}

Perkembangan jumlah penduduk tingkat kesejahteraan, ilmu pengetahuan dan teknologi memberikan juga dampak negatif terhadap keberadaan sumber daya alam hayati di negara kita, baik yang ada di daratan maupun di laut, terutama jenis yang secara alami memang tidak banyak jumlahnya. Salah satu jenis fauna laut adalah penyu sisik (Eretmachelys imbricate) yang didalam dunia konservasi populasinya di alam telah dikatagorikan "nyaris punah" atau "endangered". Ada 7 spesies penyu di dunia yaitu penyu agar/penyu pulau (Green)- Chelonia mydas., Penyu Belimbing, leatherback (Dhermochelyscoriacea), penyu karah/ penyu sisik, Hawksbill (Eretmochelys imbricata), Penyu Lekang, olive ridley (Lepidochelys olivacea), penyu lekang kempii (Lepidochelys kempii), penyu pipih, flatback (Natator depressus), penyu tempayan (Caretta caretta, L).

Penyu merupakan satwa langka yang dilindungi oleh pemerintah Indonesia dan tentunya memiliki nilai ekonomi yang tinggi sehingga perdagangan dan penyelundupan penyu terjadi di perairan Indonesia. Penyelundupan penyu merupakan tindak pidana yang sangat kompleks yang melibatkan banyak pihak mulai dari pemburu hingga eksportir, oleh karena itu Indonesia sangat penting memiliki regulasi yang tegas untuk mengatur hal-hal terkait penyelundupan penyu. Indonesia 
merupakan negara kepulauan dengan perairan dan kondisi geografis yang sangat luas sehingga rentan terhadap berbagai bentuk penyelundupan termasuk penyelundupan penyu.

Penyu internasional telah masuk dalam Appendix 1 Convention on International Trade in Endangered Species (CITES), yang artinya penyu telah dinyatakan sebagai spesies yang terancam punah dan tidak dapat diperdagangkan dalam bentuk apapun. Setelah meratifikasi Convention on International Trade in Endangered Species of Wild Fauna and Flora, pemerintah Indonesia mengambil langkah-langkah untuk melindungi penyu. Langkah pertama yang dikeluarkan pemerintah untuk melindungi penyu melalui Peraturan Menteri Pertanian tahun 1978.237/Kpts/Um/5/1978, tanggal: 29 Mei 1978, diberikan status perlindungan bagi Penyu Belimbing (Dermochelyscoriacea). Pada tanggal 4 Oktober 1980 dikeluarkan Keputusan Menteri Pertanian, yang memberikan status lindung Lepidochelys olivacea dan Caretta-caretta, 716/Kpts/10/1980. Disahkan pada tahun 1990 pada tanggal 5 Mei 1990, segala bentuk eksploitasi satwa dilindungi dilarang.

Pada tahun 1996, Peraturan Menteri Kehutanan 882/Kpts/2/1996 memberikan status lindung bagi penyu pipih (Natatordepressa). Pada tahun 1996, Peraturan Menteri Kehutanan 771/Kpts/2/1996 memberikan status perlindungan penyu (Eretmochelys imbricata). Pada tahun 1999, Peraturan Pemerintah Republik Indonesia No. 7 tahun 1999 dan Peraturan Pemerintah Republik Indonesia disahkan pada tahun 1999. Selama 8 tahun, Indonesia telah melindungi semua jenis penyu, termasuk penyu hijau. UU No 5 Tahun 1990 (selanjutnya disebut UU KSDAHE tentang perlindungan sumber daya alam dan ekosistemnya merupakan payung hukum perlindungan berbagai tumbuhan dan satwa, salah satunya kura-kura. Pasal 21 (2) UU KSDAHE (Perlindungan Sumber Daya Alam Hayati dan Ekosistem) secara jelas mengatur bahwa semua kegiatan untuk mengembangkan satwa dilindungi dilarang. Selain sanksi pidana sebagaimana diatur di atas, perdagangan satwa dilindungi, khususnya penyu juga akan dikenakan denda karena sudah melanggar asas hukum (Hamzah, 1994).

\section{Sanksi Pidana Bagi Pelaku Penyelundupan Penyu Sebagai Satwa yang Dilindungi}

Dalam menindak para pelaku peyelundupan penyu, perlu tidakan tegas untuk memberikan efek jera, misalnya pemberian sanksi pidana. Menurut Soesilo (1989) sanksi pidana ada suatu perasaan tidak enak (sengsara) yang dijatuhkan oleh hakim dengan vonis kepada orang yang telah melanggar undang-undang hukum pidana. Kejahatan penyelundupan (kejahatan penyelundupan atau penyelundupan) dapat dikaitkan dengan pelanggaran ekspor atau impor, kejahatan yang dilakukan melalui penyembunyian atau secara diam-diam, ketidakpatuhan terhadap peraturan perundangundangan yang berlaku, dan tindakan yang merugikan negara (Lopa, 1980). Indonesia telah menetapkan sanksi pidana penyelundupan sesuai dengan Pasal 102, Pasal 102 A dan Pasal 102 B UU No 17 Tahun 2006 (Hamzah, 1985). Istilah tindak pidana penyelundupan penyu, hingga saat ini belum ada undang-undang yang mengatur secara khusus tentang penyelundupan penyu. Bahkan KUHP yang merupakan aturan umum tindak pidana tidak mengatur penyelundupan. UU Konservasi Sumber Daya Alam dan Ekosistemnya (selanjutnya disebut UU KSDAHE) tidak mengatur tentang tindak pidana penyelundupan kura-kura. UU KSDAHE hanya mengatur tentang perlindungan hewan dari penangkapan, pembunuhan, penyimpanan, kepemilikan, dan pemeliharaan. Pasal $21 \mathrm{UU}$ KSDAHE ayat (2) mengatur tentang penangkapan, penyimpanan, dan pengangkutan satwa yang dilindungi termasuk penyu tanpa izin yang dapat diartikan sebagai tindakan pelanggaran hukum.

Mengenai sanksi pidana pada pelaku penyeludupan penyu dilihat dari Putusan Pengadilan Negeri Denpasar Nomor: 973/Pid.Sus/LH/2019/PN/Dps hakim menjantuhkan hukuman kepada terdakwa Penyeludupan satwa liar yang dilindungi berupa pidana penjara selama dua tahun dan pidana denda sejumlah lima puluh juta rupiah dengan tuntutan menyatakan terdakwa secara sah dan meyakinkan terbukti bersalah melakukan tindak pidana "memperniagakan, menyimpan atau memiliki kulit, tubuh, atau bagian-bagian lain satwa yang dilindungi atau barang-barang yang dibuat dari bagian-bagian tersebut atau mengeluarkannya dari suatu tempat di indonesia ke tempat lain di dalam atau di luar indonesia" sebagaimana diatur dalam Pasal 21 ayat (2) huruf d Jo Pasal 40 ayat (2) UURI No. 5 Tahun 1990 tentang Konservasi Sumberdaya Alam hayati dan Ekosistemnya menjatuhkan pidana terhadap terdakwa dengan pidana penjara tiga tahun dikurangi selama terdakwa berada dalam 
tahanan sementara dengan perintah agar terdakwa tetap ditahan dan pidana denda sebesar seratus juta rupiah subsidi air dan tiga bulan kurungan. Hakim mempertimbangkan putusan tersebut dengan pertimbanggan bahwa terdakwa terbukti terhadap barang-barang bukti berupa dua tengkorak penyu belimbing (Dermochelys eoriacea) yang ditemukan tersebut tidak memiliki dokumen persyaratan berupa dokumen CITES (Convention on International Trade ofEndangered Species), dokumen ijin impor dari Manajemen CITES Belanda, dan ijin ekspor dari Manajemen CITES (Convention on International Trade of Endangered Species). Indonesia dengan dasar menimbang bahwa benar tubuh atau bagian-bagian satwa tersebut di atas adalah merupakan, tubuh atau bagian-bagian satwa yang dilindungi oleh Undang-Undang No. 5 Tahun 1990 tentang Konservasi Sumber Daya Alam Hayati dan Ekosistemnya berdasarkan lampiran Peraturan Pemerintah (PP) No. 7 tahun 1999 tentang pengawetan jenis tumbuhan dan satwa), menimbang bahwa sebagaimana fakta-fakta hukum yang telah terungkap di hadapan persidangan tersebut telah membuktikan benar terdakwa telah memperniagakan kulit, tubuh, atau bagian-bagian lain satwa yang dilindungi atau barang-barang yang dibuat dari bagian-bagian tersebut dan memperoleh keuntungan dari perbuatannya tersebut.

Peradilan Indonesia sangat menghargai ketepatan proses hukum yang telah dilakukan oleh penyidik Kepolisian Belanda dalam melakukan penggeledehan dan pemeriksaan terhadap gudang perusahaan Timmers-Gems B.V dan Timmers-Gemsgroup B.V. yang berkedudukan di Osseweg 48 Berghem-Belanda yang kemudian menemukan fakta hukum bahwa Terdakwalah yang sudah mengirimkannya dari Indonesia dalam keterkaitan hubungan bisnis yang sudah pasti bersifat komersial (menguntungkan) bagi kedua belah pihak namun, sistem peradilan tetap menghargai hak ingkar yang dimiliki oleh Terdakwa bahkan siapapun yang dihadapkan pada persidangan, sedangkan Majelis Hakim tetap akan berpegang teguh pada fakta hukum dan peraturan perundangan-undangan yang terkait dan berlaku di Indonesia, menimbang bahwa oleh karena terdakwa tidak memiliki izin dan/tidak dapat menunjukkan dokumen terkait dengan izin untuk memperniagakan kulit, tubuh, atau bagian-bagian lain satwa berupa yang dilindungi atau barang-barang yang dibuat dari bagian-bagian tersebut dari pihak yang berwenang sebagaimana yang diharuskan oleh peraturan perundangundangan yang berlaku di Indonesia. Perbuatan yang dilakukan oleh terdakwa tersebut merupakan perbuatan yang sengaja terdakwa lakukan, artinya terdakwa mengetahui dan menghendaki bendabenda tersebut terbuat dari kulit, tubuh, atau bagian-bagian lain satwa yang dilindungi atau barangbarang yang di buat dari bagian-bagian tersebut untuk diperniagakan dan terdakwa mendapatkan keuntungan dari perbuatannya tersebut, menimbang bahwa berdasarkan pertimbangan tersebut diatas, pengadilan berpendapat unsur dengan sengaja memperniagakan kulit, tubuh, atau bagian-bagian lain satwa yang dilindungi atau barang-barang yang dibuat dari bagian-bagian tersebut" telah terpenuhi. erbuatan terdakwa telah terbukti memenuhi semua unsur tindak pidana dari pasal yang didakwakan dalam dakwaan Penuntut Umum bahwa tubuh atau bagian-bagian satwa tersebut di atas adalah merupakan tubuh atau bagian-bagian satwa yang dilindungi oleh Undang-Undang No. 5 Tahun 1990 tentang Konservasi Sumber Daya Alam Hayati dan Ekosistemnya berdasarkan lampiran Peraturan Pemerintah (PP) No. 7 tahun 1999 tentang pengawetan jenis tumbuhan dan satwa).

Perbuatan terdakwa sebagaimana diatur dan diancam pidana dalam Pasal 21 ayat (2) huruf d Pasal 40 ayat (2) UURI No. 5 Tahun 1990 tentang Konservasi Sumberdaya Alam hayati dan Ekosistemnya dan alat bukti yang diajukan di persidangan Memenuhi persyaratan dari dua alat bukti efektif yang diatur dalam Pasal 183 Konstitusi Republik Kazakhstan. Ada hubungan erat antara satu alat bukti dan bukti lainnya, yang membuat pengadilan percaya bahwa tindak pidana telah memang terjadi dan tergugat adalah tergugat. Pelaku, oleh karena itu, terdakwa harus menemukan bahwa ia telah terbukti secara sah dan meyakinkan melakukan tindak pidana dengan sengaja memperniagakan kulit, tubuh, atau bagian-bagian lain satwa yang dilindungi atau barang-barang yang dibuat dari bagian-bagian tersebut sebagaimana termuat Dalam putusannya, diperhitungkan bahwa terdakwa telah terbukti secara sah dan meyakinkan melakukan tindak pidana tersebut di atas, dan selama persidangan pengadilan tidak menemukan dalih atau alasan apapun yang dapat dijadikan dalih untuk melakukan penghapusan. . Menimbang bahwa sebelum pengadilan menjatuhkan hukuman kepada terdakwa, terdakwa harus dianggap sebagai subjek hukum yang bertanggung jawab. Oleh karena itu, 
terdakwa harus dijatuhi hukuman yang sesuai dengan kesalahannya. Pertama, perhatikan Pasal 197 (1) KUHAP dan 2009 Situasi yang memberatkan dan mitigasi terdakwa sebagaimana dimaksud dalam Pasal 28 ayat (2) UU No.48 th 2009. Atas dasar tuntutan dan pertimbangan hakim tersebut maka hakim menjatuhkan pidana kepada terdakwa oleh karena itu dengan pidana penjara selama dua tahun dan pidana denda sejumlah lima puluh juta rupiah, apabila pidana denda tersebut tidak dibayar, maka diganti dengan pidana kurungan selama dua bulan.

\section{SIMPULAN DAN SARAN}

\section{Simpulan}

Berdasarkan penjelasan diatas peneliti dapat menarik kesimpulan bahwa bentuk Perlindungan Hukum yang dibuat untuk melindungi penyu sebagai satwa yang dilindungi, yaitu dengan dibuatnya perjanjian CITES (Convention on International Trade in Endangered Species) yang merupakan Perjanjian Internasional antar pemerintah (Negara Anggota) yang ditandatangani di Washington, D.C., pada tanggal 3 Maret 1973., dimana untuk perlindungan penyu dibahas dalam appendix 1 CITES (Convention on International Trade of Endangered Species). Pemerintah Indonesia memberikan perlindungan terhadap satwa penyu dengan terdapat 6 dari 7 jenis penyu yang ada di dunia yang dilindungi berdasarkan Undang-Undang tentang Penetapan Jenis-jenis Binatang Liar Yang Dilindungi. Serta dibuatnya Undang-undang Nomor 5 Tahun 1990 (Undang-undang KSDAHE) merupakan payung hukum untuk memberi perlindungan terhadap berbagai jenis tumbuhan dan satwa, salah satunya adalah penyu. Dan bentuk sanksi terhadap orang yang menyelundupkan penyu sebagai satwa yang dilindungi adalah berupa sanksi admisnistratif, sanksi perdata dan sanksi pidana. Secara mengkhusus sanksi pidana terhadap pelaku penyeludupan penyu belum ada, sanksi tersebut masih tergabung dalam Undang-Undang No. 5 Tahun 1990 tentang Konservasi Sumber Daya Alam Hayati dan Ekosistemnya berdasarkan lampiran Peraturan Pemerintah (PP) No. 7 tahun 1999 tentang pengawetan jenis tumbuhan dan satwa.

\section{Saran}

Melalui kajian ini peneliti mengharapkan dapat memberikan perubahan pada penetapan regulasi tentang penyelundupan penyu yang merupakan kekayaan alam yang harus dilindungi. Bagi Penegak Hukum diharapkan pemberian sanksi terhadap pelaku penyeludupan penyu sebagai satwa yang dilindungi lebih baik dan tegas, serta regulasi hukum yang digunakan lebih jelas agar pelaku penyelundupan mengetahui pasti hukuman apa saja yang akan mereka terima jika melakukan penyelundupan penyu, serta dibuatkan Undang-Undang khusus yang lebih banyak dan mengikat. Kemudian, bagi pemerintah seharusnya memberikan sosialisasi kepada masyarakat terhadap penyu sebagai hewan yang dilindungi harus ditingkatkan, agar penyu tidak menjadi bahan konsumsi dan pajangan hiasan.

\section{DARTAR PUSTAKA}

Darajati, wahyuningsih et al. (2020). Indonesia Biodiversity Strategi and Action Plan. Kementrian Perencanaan Pembangunan Nasional/BAPENAS, Jakarta.

Hamzah, A. (1994). Asas-Asas Hukum Pidana (Cet.2). Rineka Cipta, Jakarta.

Hamzah, A. (1985). Delik Penyelundupan. Akademi Pressindo, Jakarta.

Lopa, B. (1980). Tindak Pidana Ekonomi: Pembahasan Tindak Pidana Penyelundupan. Pradnya Paramita, Jakarta.

Lovei, M. (2005). Going, Going, Gone, The Illegal Trade in Wildlife in East and Southeast Asia. Environtment and Social Development Department, Washington, D.C.

Putra, C. S. (2019). Perlindungan Hukum Bagi Satwa Langka Berdasarkan Keppres Nomor 43 Tahun 1978 Tentang Convention on International Trade in Endangered Species of Wild Fauna and Flora di Indonesia. Fakultas Hukum, Universitas Pasundan.

Rajardjo, S. (2006). Ilmu Hukum. Citra Aditya Bakti, Jakarta.

Soesilo, R. (1989). Kitab Undang-Undang Hukum Pidana. Politeia, Bogor. 
Jurnal Interpretasi Hukum

Vol. 2, No. 2, 2021

Syahni, N. (2018). Penegakan Hukum Terhadap Tindak Pidana Penyelundupan Penyu Sebagai Satwa Yang Dilindungi Berdasarkan Undang-Undang Nomor 5 Tahun 1990 Tentang Konservasi Sumber Daya Alam Hayati dan Ekosistemnya. Fakultas Hukum, Universitas Islam Indonesia.

Zanita, H. (2019). enyelesaian Hukum Kasus Tindak Pidana Terhadap Pembunuhan Satwa Yang Dilindungi Berdasarkan Undang-Undang No 5 Tahun 1990 Tentang Konversi Sumber Daya Alam Hayati Dan Ekosistem (Studi Di Wilayah Hukum Pengadilan Negeri Pelalawan). Fakultas Hukum, Unversitas Islam Riau. 